\title{
MORPHOGENETIC RESPONSES OF WHEAT IMMATURE EMBRYO CULTURE DEPENDING ON GROWING CONDITIONS OF DONOR PLANTS
}

\author{
L. P. Khlebova ${ }^{1}$, E. D. Nikitina ${ }^{2}$ \\ ${ }^{1}$ Altai State University, Barnaul, Russia \\ ${ }^{2}$ Altai Research Institute of Agriculture, Barnaul, Russia \\ E-mail: ${ }^{1}$ hlebova61@mail.ru; ${ }^{2}$ aniish@mail.ru
}

The article considers the influence of growth conditions of donor plants on in vitro morphogenetic responses of immature embryos from spring bread wheat. The materials were 12 varieties of different ecological and geographical origin from the collection of Altai Research Institute of Agriculture (Barnaul, Russia). Donor plants were grown in the greenhouse and experimental field near Barnaul. Immature embryos with 1.3-1.5 mm in size isolated from seeds collected 14-16 days post anthesis were used as explants. The embryos were placed with the sculletum upwards on a sterile solid agar $(0,8 \%)$ medium containing the inorganic components of Linsmaier \& Skoog (LS), 3\% sucrose, $2.0 \mathrm{mg} \mathrm{1}^{-1} 2,4-$ dichlorophenoxyacetic acid (2,4-D) and incubated in the darkness at $26 \pm 1^{\circ} \mathrm{C}$. Induced calli were subcultured after $25-30$ days interval in fresh medium supplemented with $0.5 \mathrm{mg} \mathrm{l}^{-1} 2,4-\mathrm{D}$ and $0.5 \mathrm{mg} \mathrm{l}^{-1}$ kinetin and grown at $25 \pm 1{ }^{\circ} \mathrm{C}$ under a 16/8-h (day/night) photoperiod with a white fluorescent light. Embryogenic calli were transferred to LS medium containing $0.2 \mathrm{mg} \mathrm{l}^{-1}$ indole-3-acetic acid (IAA) for regeneration. A complete randomized block design with four replications per a genotype (60 embryos) was used. We stated by analysis of the components of phenotypic variance that genetic factor has been the leading one in all stages of tissue culture, but the highest effect (80\%) was on plant regeneration. Interaction of the factors considered was competitive with genotypic influence on the stages of morphogenesis $(28 \%)$ and callusogenesis $(27 \%)$. Influence of "conditions" was statistically significant, but inferior to other factors. The greatest result was obtained for induction of morphogenic calli. Field conditions were the most favorable for genotypes with high callus and regeneration abilities. Culture responses of those with a low regeneration potential increased after growing donor plants in greenhouse vegetation in 3.4-13.9 times. For most genotypes moderate temperature and precipitation as well as natural lighting before collecting material increased morphogenic competence of explants in wheat tissue culture. Possible reasons for the influence of growth conditions of explant donor plants on in vitro culture traits have been discussed.

Keywords: spring wheat, immature embryo, donor plant, genotype, growing conditions, callus, morphogenesis, plant regeneration, variation.

\section{МОРФОГЕНЕТИЧЕСКАЯ РЕАКЦИЯ КУЛЬТУРЫ НЕЗРЕЛЫХ ЗАРОДЫШЕЙ ПШЕНИЦЫ В ЗАВИСИМОСТИ ОТ УСЛОВИЙ ВЫРАЩИВАНИЯ ДОНОРНЫХ РАСТЕНИЙ \\ ${ }^{1}$ Хлебова Л. П., ${ }^{2}$ Никитина Е. Д. \\ ${ }^{1}$ Алтайский государственный университет, Барнаул, Россия \\ ${ }^{2}$ Алтайский НИИ сельского хозяйства, Барнаул, Россия E-mail: ${ }^{1}$ hlebova61@mail.ru, ${ }^{2}$ aniish@mail.ru}

В статье рассмотрено влияние условий выращивания донорных растений на морфогенетические процессы в культуре незрелых зародышей яровой мягкой пшеницы. Материалом исследования служили 12 сортов различного эколого-географического происхождения из коллекции Алтайского НИИ сельского хозяйства (Барнаул, Россия). Донорные растения выращивали в теплице и в условиях полевой вегетации. В качестве эксплантов использованы незрелые зародыши размером 1,3-1,5 мм, изолированные на 14-16 день после опыления исходных растений. Зародыши выращивали на питательной среде Линсмайера-Скуга (LS),

\section{Следует цитировать / Citation:}

Хлебова Л.П.. Никитина Е.Д. (2016). Морфогенетическая реакция культуры незрелых зародышей пшеницы в зависимости от условий выращивания донорных растений. Acta Biologica Sibirica, 2 (2), 68-75.

Khlebova L.P., Nikitina E.D. (2016). Morphogenetic responses of wheat immature embryo culture depending on growing conditions of donor plants. Acta Biologica Sibirica, 2 (2), 68-75.

Поступило в редакцию / Submitted: 29.04.2016

Принято к публикации / Accepted: 06.06.2016

cross ref http://dx.doi.org/10.14258/abs.v2i2.1348

(C) Хлебова, Никитина, 2016

Users are permitted to copy, use, distribute, transmit, and display the work publicly and to make and distribute derivative works, in any digital medium for any responsible purpose, subject to proper attribution of authorship.

\section{(cc) EY}

This work is licensed under a Creative Commons Attribution 3.0 License 
содержащей 0,8\% агара, 3\% сахарозы, 2,0 мг/л дихлорфеноксиуксусной кислоты (2,4-Д), в темноте при температуре $26 \pm 1{ }^{\circ} \mathrm{C}$. Через $25-30$ дней каллусы переносили на дифференцирующую среду LS, дополненную 0,5 мг/л 2,4-Д и 0,5 мг/л кинетина и выращивали на свету с 16 -часовом фотопериодом (день) и температуре $25 \pm 1{ }^{\circ} \mathrm{C}$. Морфогенные каллусы переносили на среду для регенерации, содержащую 0,2 мг/л индолил-3-уксусной кислоты (ИУК). Эксперимент выполнен в четырех повторениях по 60 эксплантов на генотип. Установлено, что генетический фактор является ведущим на всех стадиях культуры ткани с максимальным эффектом на этапе регенерации (80\%). Доля фактора «взаимодействие генотип-условия» была примерно одинакова с генотипическим влиянием на этапах морфогенеза (27\%) и каллусогенеза (28\%). Влияние фактора «условия» было статистически значимо, но уступало остальным рассмотренным источникам варьирования культуральных признаков. Максимальный эффект условий выращивания доноров эксплантов был установлен при индукции морфогенного каллуса. Полевая вегетация оказалась наиболее благоприятна для генотипов с высокой каллусогенной и регенерационной способностью. Генотипы с низким регенерационным потенциалом повышали изученные признаки в 3,4-13,9 раз при выращивании растений - доноров эксплантов в условиях теплицы. Для большинства изученных сортов умеренные температура и количество осадков в период, предшествующий отбору материала, а также естественное освещение способствовали повышению морфогенной компетенции эксплантов после их введения в культуру. В статье обсуждаются возможные причины влияния условий выращивания материнских растений на эффективность каллусо-, морфогенеза и регенерации в культуре ткани пшеницы in vitro.

Ключевые слова: яровая пшеница, незрельй зародыш, растение-донор, генотип, условия выращивания, каллус, морфогенез, регенерация растений, изменчивость.

\section{INTRODUCTION}

Wheat (Triticum aestivum L.) is one of the most important food and feed crops in many countries grown on about $17 \%$ of the world's cultivable land (over 200 million hectares) (Atchison et al., 2010). In the early 1960s as a result of the Green Revolution, conventional breeding led to a significant increase of wheat production through developing responsive, semi dwarf, high yielding varieties and improved farm management practices. At the same time, the Green Revolution has affected negative the environment through the using herbicides, pesticides and chemical fertilizers leading to enhancing pollution and soil erosion. Besides, the environment was also influenced by the large irrigation systems that have required to keep up the growth of the plants resulted in water deficiency and droughts.

Now according to the FAOs data there has been a downward trend in world wheat production (FAO, 2011). Besides, the global demand for food will most likely increase in the coming 40-50 years because of continuing population and consumption growth. These challenges need modern approaches to improve wheat. Traditional and marker assisted selection (MAS) are unlikely to bring improvement in wheat breeding because of the limited gene-pool (Vasil, 2007). In current situation plant biotechnology plays an important role in meeting this demand and will contribute great to maintaining yield stability by generating varieties with improved resistance to biotic and abiotic stresses rather than raising the overall yield. Genetic engineering offers one of the ways to solve this problem. To introduce novel as well as alien genes into wheat is possible by genetic transformation.

Transgenic wheat plants can be regenerated through particle bombardment and Agrobacterium transformation (Patnaik \& Khurana, 2001; Bhalla, 2006; Mamrutha et al., 2014). Success of genetic engineering depends on effective and reproducible plant regeneration systems. I think morphogenesis in vitro is one of the most complex and difficult regulated processes. Various explant sources, such as immature embryos, immature inflorescence, immature leaves, mature embryos, mesocotyls and apical meristem have been used for callus induction and plant regeneration in wheat (Maddock et al., 1983; Benkirane et al., 2000; Salyaev et al., 2001; Wang \& Wei, 2004; Avksentyeva \& Petrenko, 2009; Kruglova \& Katasonova, 2009; Bychkova, 2016). According to many researchers immature embryos are the most preferred explants for genetic transformation because of their high regeneration capacity (Jones, 2005; Chauhan et al., 2007). Callus induction and regeneration frequency of wheat depends first of all on a genotype (Grigorieva \& Shletser, 2006; Nasircilar et al., 2006; Avksentyeva et al., 2008; Nikitina et al., 2014) and culture conditions (Przetakiewicz et al., 2003; Pellegrineschi et al., 2004; Mokhtari et al., 2013; Nikitina et al., 2013a; Zhang et al., 2014).

About anther culture it proved the growth conditions of donor plants affect strong the ability to androgenesis (Han et al., 2010), but in relation to immature embryo culture the opinions are different. Maddock et al. (1983) found no difference between the abilities of immature wheat embryos grown under different conditions to callus formation. However, Hess \& Carman (1998), Pastori et al. (2001) stated the regeneration efficiency of the explant affected high by its physiological status, depending mainly on environmental temperature before collecting samples. According to our studies made earlier, we have observed that the reactions of some genotypes of wheat varied depending on the maternal environment (Grigorieva \& Shletser, 2006; Nikitina et al., 2013b; Nikitina \& Khlebova, 2014). In addition, Hess \& Carman (1998) reported that individual explants of incompetent lines sometimes occasionally revealed a favorable response to in vitro culture suggesting a more critical assessment of donor growth conditions. Thus, these data do not give a clear 
picture of the effect of growing conditions for explant donor plants on the variability of morphogenetic processes in the in vitro culture. To deepen knowledge in this subject, the aim of this research was to test the morphogenetic potential of callus cultures from immature embryos of spring bread wheat depending on the conditions of growth and development of explant donor plants.

\section{MATERIALS AND METHODS}

The materials were 12 spring bread wheat varieties of different ecological and geographical origin. The genotypes were chosen from the collection of Altai Research Institute of Agriculture (Barnaul, Russia) by contrasting expression for different agronomic traits as well as a high-level of variation for in vitro culture processes (Grigorieva \& Shletser, 2006; Nikitina et al., 2015).

Donor plants were grown in the greenhouse and experimental field near Barnaul. The trails were set up according to a randomized complete block design. The date of anthesis for each variety has been determined when $50 \%$ of the ears were at this stage. Greenhouse growing season was lasting from January to May, the average temperature varied in the range $21.0-24.9^{\circ} \mathrm{C}$. During February, March, April and May illumination increased gradual reaching 14.5; 17.8; 19.1, and $22.0 \mathrm{klx}$. In the greenhouse DMZ 3000 lamps produced supplementary lighting which increased the level of natural light by $10 \mathrm{klx}$. The illumination in the field on the clear sunny days was above $50 \mathrm{klx}$, but in cloudy weather this option was 10-14 klx. The average monthly temperature in May, June, July, and August was equal to $12.7 ; 19.0 ; 21.5$, and $16.5{ }^{\circ} \mathrm{C}$ respective. Environmental data were taken from the nearest meteorological station located at a distance of $300 \mathrm{~m}$.

Immature embryos with $1.3-1.5 \mathrm{~mm}$ in size isolated from seeds collected $14-16$ days post anthesis were used as explants. Seeds were sterilized in the laminar flow chamber by successive immersion into $70 \%$ ethanol for one min, commercial $\mathrm{NaOCl}$ bleach solution (8\% active chlorine) with a few drops of Tween-20 for 15 min, and rinsed five times with sterile distilled water. The embryos were aseptic excised from the seeds using a sterile dissecting needle, placed with the sculletum upwards on a sterile solid agar $(0,8 \%)$ medium containing the inorganic components of Linsmaier \& Skoog (LS) (Linsmaier \& Skoog, 1965), 3\% sucrose, $2.0 \mathrm{mg} \mathrm{l}^{-1}$ 2,4dichlorophenoxyacetic acid (2,4-D) and incubated in the darkness at $26 \pm 1{ }^{\circ} \mathrm{C}$. The $\mathrm{pH}$ of the medium was adjusted to 5.8. Induced calli were subcultured after 25-30 days interval in fresh medium supplemented with $0.5 \mathrm{mg} \mathrm{l}^{-1} 2,4-\mathrm{D}$ and $0.5 \mathrm{mg} \mathrm{l}^{-1}$ kinetin and grown at $25 \pm 1{ }^{\circ} \mathrm{C}$ under a $16 / 8$-h (day/night) photoperiod with a white fluorescent light. Embryogenic calli were transferred to LS medium containing $0.2 \mathrm{mg} \mathrm{l}^{-1}$ indole-3-acetic acid (IAA) for regeneration. When the seedlings have reached 5-7 cm they were planted in pots with the soil through a gradual acclimatization process and grown before ripening in a climate chamber at $12{ }^{\circ} \mathrm{C}$ at night and $17{ }^{\circ} \mathrm{C}$ during the day under $16-\mathrm{h}$ illumination.

A complete randomized block design with four replications per a genotype (60 embryos) was used. The following parameters were calculated: the number of calli/total of embryos plated (callusogenesis, \%), the number of morphogenic calli/total of calli (morphogenesis, \%), the number of plantlets/total of morphogenic calli (plant regeneration, \%). The effects of genotype and growing conditions for donor plants on culture responses were determined by two-way analysis of variance (ANOVA). The least significant difference test (LSD) was used for comparing the means of tissue culture traits by genotypes and environmental conditions. Statistical analysis was performed using the STATISTICA package.

\section{RESULTS}

Analysis of variance showed the main effects of a genotype, donor growth conditions and interaction between the two were all significant at the $\mathrm{p} \leq 0.01$ or $\mathrm{p} \leq 0.05$ for callusogenesis, morphogenesis and plant regeneration (Table 1).

Table 1. Effects of genotypes and growing conditions for donor plants on culture responses of immature embryos from spring bread wheat

\section{Source of variation}

\begin{tabular}{|c|c|c|c|}
\hline \multirow[b]{2}{*}{ Source of variation } & \multicolumn{3}{|c|}{ F-test } \\
\hline & Callusogenesis & Morphogenesis & $\begin{array}{c}\text { Plant } \\
\text { regeneration }\end{array}$ \\
\hline Genotype & $4.5^{*}$ & $6.7 * *$ & $50.8 * *$ \\
\hline Conditions & $5.3^{*}$ & $20.6 * *$ & $6.6^{*}$ \\
\hline Genotype $\mathrm{x}$ Conditions & $3.1 * *$ & $5.8 * *$ & $6.0^{* *}$ \\
\hline $\mathrm{LSD}_{0,05}$ & 4,0 & 9,7 & 14,3 \\
\hline
\end{tabular}

$\mathrm{F}-$ the real value of the F-test on the factor; *,** - significant at $\mathrm{p} \leq 0.01$ and $\mathrm{p} \leq 0.05$ respective.

In the field growing season of explant donor plants mean frequency of callus induction was $91.7 \%$ ranging from 76.6 (Skala) to $100.0 \%$ (Tselinnaya 20, Altaiskaya 88, and Rossiyanka) (Figure 1). When donor plants were grown under greenhouse conditions, the result was much lower $(87.6 \%)$. However, the reaction of genotypes to the environment turned out to be different. For some varieties (Skala, Spectr, Zhnitsa, and 


\section{Acta Biologica Sibirica}

Zarnitsa) the best conditions were the greenhouse ones, while most samples induced cell lines much more effective from the field grown explants.

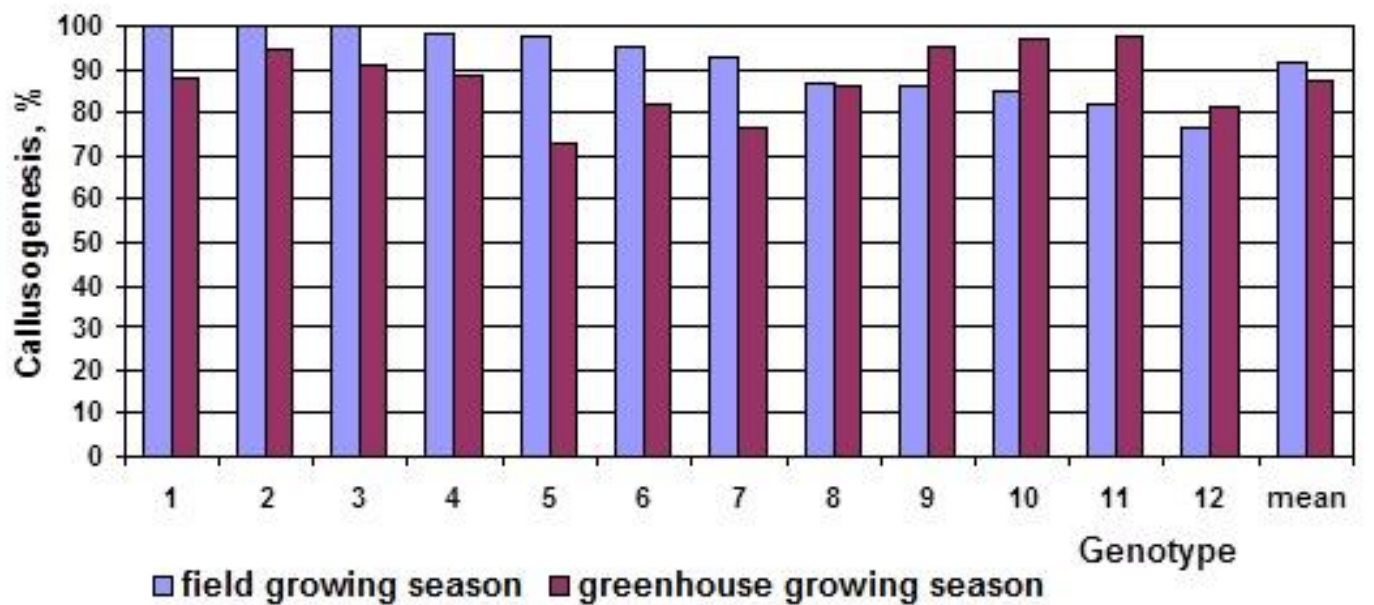

Figure 1. Callus induction frequency from immature embryos of spring bread wheat, $\%$ :

1 - Tselinnaya 20; 2 - Altaiskaya 88; 3 - Rossiyanka; 4 - Altaiskaya 81; 5 - Botanicheskaya 2; 6 - Leones;

7 - Tulunskaea 10; 8 - Altaiskaya 50; 9 - Zarnitsa; 10 - Spectr; 11 - Skala; 12 - Zhnitsa

About morphogenesis on average across all varieties more effective result was obtained from field-grown donor plants (65.7\%) showing the wide variability (28.4-91.2\%). The average frequency of morphogenic calli from indoors explants was $55.7 \%$ (Figure 2) revealing a decrease of embryogenic abilities for the most varieties except for Tulunskaya 10, Zarnitsa, and Altaiskaya 88. It should be noted a significant reduction in the variability of the characteristic depending on the donor genotype (43.8-76.7\%).

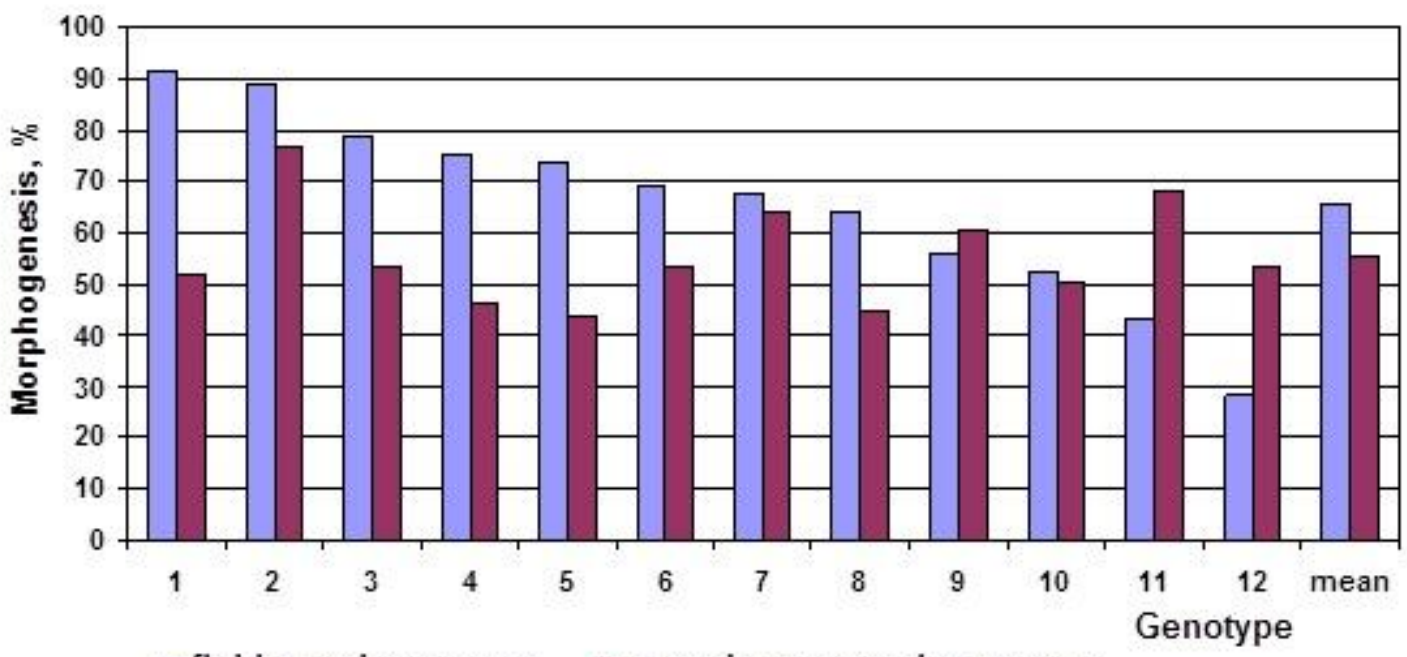

$\square$ field growing season $\square$ greenhouse growing season

Figure 2. Morphogenic callus frequency from immature embryos of spring bread wheat, \%:

1 - Leones; 2 - Skala; 3 - Spectr; 4 - Tselinnaya 20; 5 - Botanicheskaya 2; 6 - Altaiskaya 50; 7 -

Rossiyanka; 8 - Zhnitsa; 9 - Altaiskaya 88; 10 - Altaiskaya 81; 11 - Zarnitsa; 12 -Tulunskaea 10

The regeneration processes were also active induced in cell cultures derived from the explants of summer growing season (Figure 3). However, these environmental conditions had a favorable impact on the regeneration of five varieties (Skala, Leones, Spectr, Tselinnaya 20, and Zhnitsa) and reduced plant output from the other genotypes. It is remarkable that the samples with a low regeneration activity increased its by using greenhouse conditions. As a result, the plant output from Altaiskaya 81, Altaiskaya 88, Altaiskaya 50, and Rossiyanka have increased by $3.4 ; 7.0 ; 8.6$, and 13.9 times respective. These varieties have provided a low output of regenerants from explants grown in a field, despite the relative high proportion of morphogenic calli $(52.6-69.0 \%)$. This can be explained by the majority of morphogenic cell lines developed roots but not plants. Thus, the conditions of ex vivo embryo formation (future explants) in the greenhouse after introducing them to the culture induced proliferation of morphogenic calli developing further by embryogenesis and gemmogenesis. This led to significant changes in the path of morphogenesis and raised the output of regenerans. 


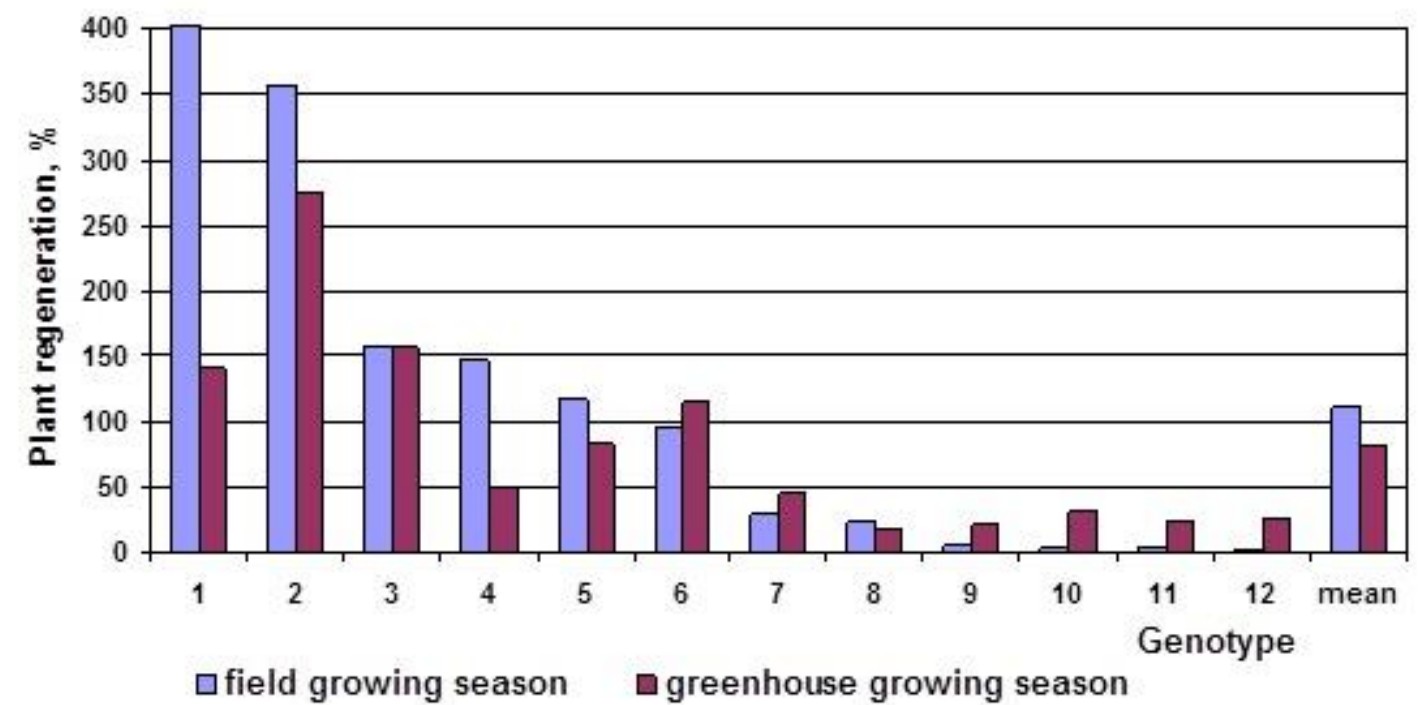

Figure 3. Plant regeneration from immature embryos of spring bread wheat (of morphogenic calli), \%: 1 - Spectr; 2 - Skala; 3 - Tulunskaea 10; 4 - Leones; 5 - Zhnitsa; 6 - Botanicheskaya 2; 7 - Zarnitsa; 8 -

Tselinnaya 20; 9 - Altaiskaya 81; 10 - Altaiskaya 50; 11 - Altaiskaya 88; 12 - Rossiyanka

\section{DISCUSSION}

The relative values of the sources of variation have great varied as showed by the variance components. Comparison of contribution of different variation sources (as a percentage of the total variation) showed the advantage of main genotype effect at all stages of in vitro culture (33-80\%) (Figure 4). The main effect of "genotype $\times$ conditions" interaction explained 27,28 , and $9 \%$ of the total sum of squares for callusogenesis, morphogenesis and plant regeneration respective. Different genotypes subjected to identical changes in the environment have reacted to it in different ways. The impact of "conditions" of explant donor growth was constant but low ranging from one to $9 \%$ depending on the stage of culture development. Still field conditions promoted a significant increase of the mean values of the processes studied. Callus formation, morphogenesis and plant regeneration increased by $4.1 ; 10.0$ and $30.5 \%$ respective.

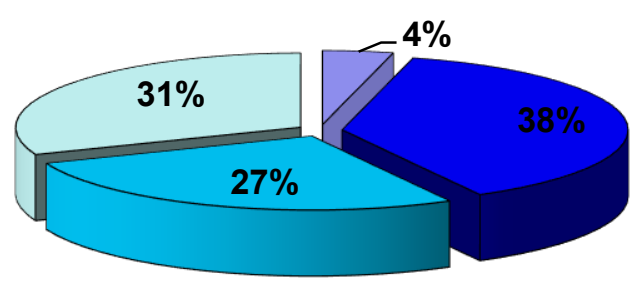

Callusogenesis

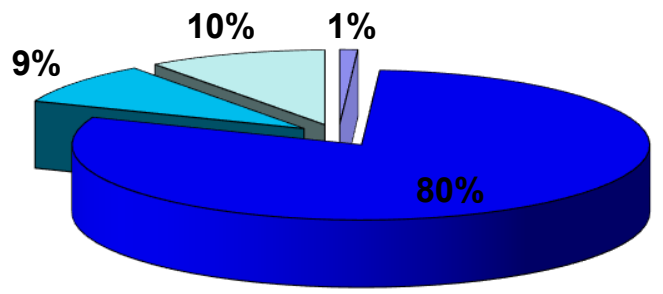

Plant regeneration

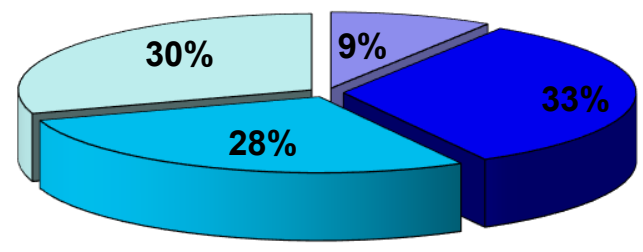

Morphogenesis

-Genotype

口Genotype x Conditions

\section{$\square$ Residual}

Figure 4. The percentage of the sources of variation of culture responses from immature embryos of spring bread wheat

Thus, we stated by analysis of the components of phenotypic variance that genetic factor has been the leading one in all stages of tissue culture, but the highest effect (80\%) was on plant regeneration. Interaction of the factors considered was competitive with genotypic influence on the stages of morphogenesis (28\%) and 
callusogenesis $(27 \%)$. Influence of "conditions" was statistically significant, but inferior to other factors. The greatest result was obtained for induction of morphogenic calli. In contrast, according to Mitić et al. (2006) the study of 96 wheat varieties under three vegetations showed that factor "year" had the highest impact on expression of callus formation and reached $71.4 \%$. However, the effects of genotype as well as interaction of the factors were about the same as in this experiment. Further test of the influence of climatic factors on the immature embryo culture potential of the same varieties showed that the lack of rainfall and high temperatures especially in the period between flowering and medium milk stage decreased tissue culture traits of most genotypes (Dodig et al., 2010). Moreover, callus induction and proliferation were the most sensitive to a temperature factor.

Investigation herein, the seed collection for the isolation of explants took place in the first half of July in the summer growing season and in mid-March in the greenhouse vegetation. The mean temperatures during these periods of plant growth were 19.5 and $25.9{ }^{\circ} \mathrm{C}$ respectively. Besides, plant growing in the greenhouse was held at a lower illumination versus field season. Heat and poor lighting can be considered as a stress for the development of embryos. We suggest greenhouse conditions were a limiting factor for their quality which led to a decrease in the embryogenic competence of explants. Wang et al. (2014) reported also that high temperatures significantly affected the induction of morphogenic calli as well as plant regeneration from immature wheat embryos. They calculated the optimum total accumulated temperature between wheat anthesis and collecting material for tissue culture experiment was about $280^{\circ} \mathrm{C}$ for spring wheat. This is consistent with our data, taking into account the time of sampling in the field growing season. We collected seeds 14-16 days post anthesis. The total accumulated temperature in the greenhouse vegetation during this period significantly exceeds the optimum reaching about $380{ }^{\circ} \mathrm{C}$.

Hess \& Carman (1998) explained morphogenic competence of wheat explants their hormonal status. A special role is played by the absolute levels or endogenous auxin to cytokinin ratios. According to their data, embryogenic competence was due to low IAA and ABA levels in seeds from zero to 12 days post anthesis, high zeatin to IAA ratios at four days post anthesis, and high cytokinin to auxin ratios in the induced calli. The authors hypothesized environmental conditions that decrease endogenous hormone levels during this period should induce or prolong embryogenic competence of explants regardless of wheat genotype. As mentioned above efficiency of morphogenesis and especially regeneration not in all genotypes was higher when donor plants were grown in field vegetation. Poorly embryogenic varieties contrary gave rise culture traits from embryos collected in greenhouse (Figures $1-3$ ). We guess this might be caused by environmental parameters that inhibit hormone accumulation in seeds before culturing.

\section{CONCLUSIONS}

Thus, various culture traits from immature wheat embryos depended more on heredity of varieties and to some extent on the environmental conditions in which these varieties were grown. The reaction of each genotype was specific. Field conditions were the most favorable for genotypes with high callus and regeneration abilities. Culture responses of those with a low regeneration potential increased after growing donor plants in greenhouse vegetation. For most genotypes moderate temperature and precipitation as well as natural lighting before collecting material increased morphogenic competence of explants in wheat tissue culture.

\section{REFERENCES}

Atchison, J., Head, L., Gates, A. (2010). Wheat as food, wheat as industrial substance; comparative geographies of transformation and mobility. Geoforum, 41, 236-246.

Avksentyeva, O.A., Petrenko, V.A. (2009). Role of the genotype, composition of medium and type of explant in formation of the first callus of wheat isogenic lines. Visnik Harkivskogo nacionalnogo universitetu imeni V.N. Karazina. Seriya. Biologiya, 9(856), 56-62 (in Russian).

Avksentyeva, O.A., Petrenko, V.A., Tichenko, A.A., Zhmurko, V.V. (2008). Callus initiation and morphogenesis in in vitro culture of isogenetic on gene type and rate of development in winter wheat lines. Annual Wheat Newsletter, 54, 150-152.

Benkırane, H., Sabounj, S., Chlyah, A., Chlyah, H. (2000). Somatic embryogenesis and plant regeneration from fragments of immature inflorescences and coleoptiles of durum wheat. Plant Cell Tissue and Organ Culture, 61, 107-113.

Bhalla, P.L. (2006). Genetic engineering of wheat - current challenges and opportunities. Trends Biotechnol, $24,305-311$.

Bychkova, O.V. (2016). Evaluation of morphogenesis and regeneration of hard spring wheat in vitro. Acta Biologica Sibirica, 2(1), 139-149 (in Russian).

Chauhan, H., Desai, S.A., Khurana, P. (2007). Comparative analysis of the differential regeneration response of various genotypes of Triticum aestivum, Triticum durum and Triticum dicoccum. Plant Cell Tiss Org Cult, 91, 191-199. 
Dodig, D., Zorić, M., Mitić, N., Nikolić, R., King, S.R., Lalević, B., Šurlan-Momirović, G. (2010). Morphogenetic responses of embryo culture of wheat related to environment culture conditions of the explant donor plant. Sci. Agric. (Piracicaba, Braz.), 67(3), 295-300.

Food and Agriculture Organization (2011). Global cereal supply and demand brief. Crop Prospects and Food Situation, 1, 4-5.

Grigorieva, L.P., Shletser, I.A. Screening wheat caltivars for morphogenesis ability in immature embryo culture in vitro. (2006). Izvestiya altajskogo gosudarstvennogo universiteta, $\underline{3}, 64-66$ (in Russian).

Han, X.F., Tao, L.L., Yin, G.X., Liu, X.L., Du, L.P., Wei, Y.Q., Yan, Y.M., Ye, X.G. (2010). Effect of genotype and growing environment on anther culture in wheat. Acata Agronomica Sinica, 36, 12091215.

Hess, J.R., Carman, J.G. (1998). Embryogenic competence of immature wheat embryos: genotype, donor plant environment and endogenous hormone levels. Crop Science, 38, 249-253.

Jones, H.D. (2005). Wheat transformation: current technology and applications to grain development and composition. J. Cereal Sci, 41, 137-147.

Kruglova, N.N., Katasonova, A.A.(2009). Immature wheat embryo as the morphogenetically competent explant. Fiziologiya i bioximiya kulturnyh rastenij, 41(2), 124-131 (in Russian).

Linsmaier, E., Skoog, F. (1965). Organic growth factor reqularments of tobacco tissue culture. Physiol. Plant, $18(1), 100-127$.

Maddock, S.E., Lancaster, V.A., Risiott, R., Franklin, J. (1983). Plant regeneration from cultured immature embryos and inflorescences of 25 cultivars of wheat (T. aestivum). J. Exp. Bot, 34(144), 915-926.

Mamrutha, H.M., Kumar, R., Venkatesh, K., Sharma, P., Kumar, R., Tiwari, V., Sharma, I. (2014). Genetic transformation of wheat - Present status and future potential. Journal of Wheat Research, 6(2), 107119.

Mitić N., Dodig, D., Nikolić R. (2006). Variability of in vitro culture response in wheat genotypes, genotype and environmental effects. Genetika, 38(3), 183-192.

Mokhtari, A., Alizadeh, H., Samadi, B.Ya., Omidi, M., Otroshy, M., Moeini, Z. (2013). Effect of plant growth regulators on direct shoot regeneration of wheat immature embryonic explants. Journal of Agricultural Engineering and Biotechnology, 1(3), 74-80.

Nasircilar, A.G., Turgut, K., Fiscin, K. (2006). Callus induction and plant regeneration from mature embryos of different wheat genotypes. Pak. J. Bot, 38(2), 637-645.

Nikitina, E.D., Khlebova, L.P., Sokolova, G.G. (2013a). The development of Ni-resistance sources of spring wheat by cell selection in vitro. Izvestiya altajskogo gosudarstvennogo universiteta, 3-1(79), 88-90 (in Russian).

Nikitina, E.D., Khlebova, L.P., Sokolova, G.G., Ereschenko, O.V. (2013b). The development of stressresistant stock of spring bread wheat by in vitro cell selection. Izvestiya altajskogo gosudarstvennogo universiteta, 3-2(79), 95-98. (in Russian). DOI: 10.14258/izvasu(2013)3.2-20.

Nikitina, E.D., Khlebova, L.P. (2014). The influence of temperature and light on direct sprouting of Triticum aestivum L. immature embryos in vitro. Izvestiya altajskogo gosudarstvennogo universiteta, 3-1(83), 46-50 (in Russian).

Nikitina, E.D., Khlebova, L.P., Ereschenko, O.V. (2014). The development of some technology elements of the spring wheat cell selection for resistance to abiotic stresses. Izvestiya altajskogo gosudarstvennogo universiteta, 3-2(83), 50-54 (in Russian). DOI: 10.14258/izvasu(2014)3.2-09.

Nikitina, E.D., Khlebova, L.P., Pronina, R.D. (2015). In vitro somaclonal variation as initial material for bread wheat breeding. Acta Biologica Sibirica, 1(3-4), 171-186 (in Russian).

Patnaik, D., Khurana, P. (2001). Wheat biotechnology: A minireview. Electronic Journal of Biotechnology, 4(2), 1-29.

Pellegrineschi, A., Brito, R.M., McLean, S., Hoisington, D. (2004). Effect of 2,4-dichlorophenoxyacetic acid and $\mathrm{NaCl}$ on the establishment of callus and plant regeneration in durum and bread wheat. Plant Cell, Tissue, Organ Culture, 77(3), 245-250.

Przetakiewicz, A., Orczyk, W., Nadolska-Orczyk A. (2003). The effect of auxin on plant regeneration of wheat, barley and Triticale. Plant Cell, Tissue and Organ Culture, 73(3), 245-256.

Salyaev, R.K., Dudareva, L.V., Lankevich, S.V., Sumtsova, V.M. (2001). The effect of low-intensity coherent radiation on the processes of morphogenesis in the wheat callus culture. Dokl. Akad. Nauk, 376, 830 832.

Vasil, I.K. (2007). Molecular genetic improvement of cereals: transgenic wheat (Triticum aestivum L.). Plant Cell Rep, 26, 1133-1154.

Wang, X.M., Ren, X., Yin, G.X., Wang, K., Li, J.R., Du, L.P., Xu, H.J., Ye, X.G. (2013). Effects of environmental temperature on the regeneration frequency of the immature embryos of wheat (Triticum 
Acta Biologica Sibirica

aestivum L.). Journal of Integrative Agriculture. Advanded Online Publication. DOI: 10.1016/S20953119(13)60361-5.

Wang, C., Wei, Z. (2004). Embriogenesis and regeneration of green plantlets from wheat (Triticum aestivum L.) leafbase. Plant Cell, Tissue and Organ Culture, 77(2), 149-153.

Zhang, W., Wang, X., Fan, R., Yin, G., Wang, K., Du, L., Xiao, L., Yt, X. (2014) Effects of inter-culture, arabinogalactan proteins, and hydrogen peroxide on the plant regeneration of wheat immature embryos. Journal of Integrative Agriculture. Advanded Online Publication. DOI: 10.1016/S20953119(14)60764-4. 